Kebijakan Penataan Minimarket dan Pemberdayaan Pedagang Tradisional

di Kota Bandung: Studi di Kawasan Pemukiman Kecamatan Antapani (Budiman Rusli)

\title{
KEBIJAKAN PENATAAN MINIMARKET \\ DAN PEMBERDAYAAN PEDAGANG TRADISIONAL DI KOTA BANDUNG: STUDI DI KAWASAN PEMUKIMAN KECAMATAN ANTAPANI
}

\author{
Budiman Rusli \\ Fakultas Ilmu Sosial dan IImu Politik Universitas Padjadjaran \\ E-mail: prof.budiman_rusli@yahoo.com
}

\begin{abstract}
ABSTRAK. Penelitian ini menyoroti masalah kebijakan penataan pasar modern dalam hal ini mini market yang belum berjalan sesuai harapan. Ditemukan banyak pelanggaran yang menyebabkan para pedagang tradisional tersudutkan bahkan tidak sedikit yang gulung tikar. Lokasi penelitian ini di kawasan pemukiman Kecamatan Antapani yang tediri dari empat kelurahan yaitu; Kelurahan Antapani Wetan, Kelurahan Antapani Kulon, Kelurahan Antapani Tengan dan Kelurahan Antapani Kidul. Pendekatan yang dilakukan dalam penelitian ini adalah kualitatif. Data diperoleh melalui indepth interview, observasi, studi literature dan pengumpulan data sekunder. Adapun informan pada penelitian ini adalah pejabat perijinan BPPT, Disperindag KUKM, Camat Antapani, Minimarket dan Ritel Tradisional di Kecamatan Antapani. Berdasarkan hasil penelitian, diketahui bahwa implementasi Kebijakan Penataan minimarket belum berjalan sesuai dengan harapan. Perkembangan usaha ritel modern masih mendominasi perekonomian masyarakat. Belum ada usaha yang berhasil secara signifikan memberdayakan para pedagang tradisional agar siap bersaing merebut pasar potensial yaitu konsumen yang bermukim di sekitar kawasan perumahan tersebut.Pelanggaran demi pelanggaran masih terjadi. Berdampak pada penurunan omzet yang sangat tajam melampaui angka $70 \%$ yang membuat pelaku ekonomi yang lemah ini tersudutkan dan tidak sedikit yang gulung tikar. Dari hasil penelitian di lapangan, penulis menemukan salah satu poin penting dalam mendukung pelaksanaan kebijakan ini melalui memperkuat pola kemitraan. Model kemitraan yang kuat akan menjadi penopang utama kelancaran implementasi kebijakan. Dalam penelitian ini, penulis mengajukan "Model Kemitraan MRT," sebagai model alternatif dalam mengatasi hambatan dan masalah implementasi Kebijakan Penataan Pasar Tradisional, Pusat Perbelanjaan dan Toko Modern yang diamanatkan Perda Kota Bandung Nomor 2 Tahun 2009.
\end{abstract}

Kata Kunci: Kebijakan, Minimarket dan Ritel Tradisional

\section{STRUCTURING POLICY MINIMARKETTRADITIONAL TRADERS AND EMPOWERMENT IN BANDUNG CITY: STUDIES IN RESIDENTIAL AREA DISTRICT ANTAPANI}

ABSTRACT. This research is concern to the problem of the modern market structuring policy in this mini-market that has not run as expected. Found many violations that cause the traditional traders cornered even quite a few are out of business. Research sites in residential areas Antapani District consisting of four 
villages namely; east Antapani, west Antapani, at central and south Antapani. This research used qualitative method. Data obtained through in-depth interviews, observation, study of literature and secondary data collection. The informants in this study is licensing officials BPPT, Industrial and trade service of Small and Medium Enterprises, Head Antapani, Minimarket and Traditional Retail in Antapani sub-district. Based on this research, it is known that the implementation of the Settlement Policy minimarket not run in line with expectations. The Growth of modern retail businesses still dominate the economy. There has been no successful effort to significantly empower the traditional traders to be ready to compete seize potential market of consumers who live in the surrounding residential area. Violations of this policy still happen. Impact of this situation decrease $70 \%$ of income in traditional retail and small part of them bankrupt. The results of research the authors found one of the important points in supporting the implementation of this policy through a strengthened partnership. Strong partnership model will be the mainstay of the smooth implementation of the policy. In this research the authors propose "MRT Partnership Model," as an alternative model in overcoming obstacles and problems of policy implementation Arrangement Traditional Market, Shopping Centers and Stores Modern mandated by local policy of Bandung No.2/ 2009.

Keyword: Policy, Minimarket, Traditional Traders

\section{PENDAHULUAN}

Dalam Undang-undang nomor 20 tahun 2008, tentang Usaha Mikro,Kecil dan Menengah, dijelaskan bahwa Minimarket dikatagorikan sebagai Pasar Modern yang tidak termasuk kriteria Usaha Kecil dan Menengah, karena manajemen pengelolaannya diselenggarakan oleh perusahaan besar dan barang yang dijual beragam serta dalam kuantitas yang relatif banyak, bisa mencapai puluhan ribu item barang. Dari segi tempat lebih tertata dan dikelola dengan manajemen modern. Kesempatan tawar menawar harga dengan konsumen atau pelanggan menjadi tertutup dengan sistem harga pas. Sedangkan Pasar atau Pedagang Tradisional sangat sederhana baik dari segi metode maupun teknologi. Barang yang dijual terbatas. Selain itu, manajemen masih tradisional terutama dalam hal keuangan belum menerapkan sistem yang sesuai kaidah norma keuangan. Seringkali pengelolaan keuangan dengan biaya hidup keluarga menjadi satu sehingga stabilitas modal usaha sering terganggu. Tawar menawar harga dengan konsumen atau pelanggan yang bisa menghabiskan waktu lama menjadi ciri khas pula.

Untuk mengantisipasi munculnya kanibalisme pelaku usaha modern seperti Mini market ini terhadap pelaku usaha lemah dalam hal ini pasar atau Pedagang Tradisional, , diperlukan pembinaan dan penataan sehingga para pelaku usaha perdagangan ini bisa sama-sama tumbuh. 
Kebijakan Penataan Minimarket dan Pemberdayaan Pedagang Tradisional

di Kota Bandung: Studi di Kawasan Pemukiman Kecamatan Antapani (Budiman Rusli)

Dalam perkembangannya, minimarket menjadi salah satu bentuk pasar modern dengan jumlah yang sangat besar dan tersebar di hampir seluruh pelosok di tanah air. Bahkan kini, minimarket masuk ke desa-desa dan kelurahan bahkan bisa masuk ke perumahan atau pemukiman penduduk.

Liberalisasi pasar modern dan ritel yang berawal pada tahun 1998 membuat para pengusaha asing masuk ke pusat-pusat kota di Indonesia. Hal ini menjadi salah satu alasan ritel modern lokal menjamur ke daerah permukiman.

Mini market sebagai ritel-ritel atau toko modern melesakkan strategi pengembangan usahanya ke kota-kota kecamatan, pinggiran kota, desa-desa bahkan pelosok sekalipun. Hal ini dilakukan karena pada pusat kota sudah begitu banyak hypermarket dan supermarket. Selain itu minimarket sengaja mendekati konsumen akhir yaitu masyarakat yang bermukim .

Kenyataan tersebut menyudutkan Pedagang Tradisional baik berupa pasar, kios, warung maupun toko. Keterbatasan modal, sumber daya manusia dan lemahnya keterampilan manajemen usaha membuat daya saing mereka semakin terpuruk dan tertekan oleh industri minimarket.

Fenomena tersebut juga muncul di kawasan Antapani Kota Bandung. Antapani menjadi lokasi pilihan peneliti karena keunikannya sebagai daerah urban. Antapani memiliki minimarket yang cukup besar untuk ukuran sebuah kawasan pemukiman yaitu 16 minimarket. Gaya hidup yang lebih modern disebabkan tumbuh pesatnya perumahan mewah yang dihuni kalangan menengah ke atas dengan gaya hidup modern. Kondisi ini membawa kecenderungan masyarakat Antapani menjadi sasaran empuk ritel modern.

Tabel 1. Minimarket di Kecamatan Antapani

\begin{tabular}{|c|c|}
\hline NAMA MINIMARKET & ALAMAT \\
\hline Alfamart & JL. Tanjungsari \\
\hline Indomart & JL. Terusan Jakarta \\
\hline Griya Mart & JL. A.H. Nasution \\
\hline Alfamart * & JL. Antapani \\
\hline Indomart & JL. Terusan Jakarta \\
\hline Alfamart & JL. Parakan Saat \\
\hline Alfamart & JL. Kuningan \\
\hline Indomart & JL. Terusan Jakarta \\
\hline SB Mart * & JL. Cibatu \\
\hline Yomart & JL. Parakan Saat \\
\hline Yomart & JL. Kuningan \\
\hline Alfamart & JL. Indramayu \\
\hline Indomart & JL. Indramayu \\
\hline Indomart & JL. Karang Asem \\
\hline Griya & JL. Purwakarta \\
\hline Yomart & JL. Purwakarta \\
\hline
\end{tabular}

Sumber : Kantor Kecamatan Antapani, 2011 
Yang menjadi permasalahan adalah bagaimanakah nasib para pengusaha ritel tradisional yang selama ini ada di kawasan Antapani. Apakah mereka mampu bersaing? Padahal menurut informasi jumlah ritel tradisional di Antapani mencapai ribuan.

Berdasarkan hasil wawancara dengan beberapa warung tradisional menunjukkan bahwa mereka mengalami penurunan omzet yang sangat drastis. Sejak adanya minimarket di Antapani, mereka merasakan sekitar $50-70 \%$ omzet menurun. Bahkan sebagian warung tradisional mengalami gulung tikar.

Kondisi tersebut makin diperparah dengan perpanjangan jam buka minimarket sampai 24 jam yang dilakukan oleh Alfamart dan Indomart. Sehingga para peritel kecil berupa warung-warung yang ada di pinggir jalan yang menggunakan selter atau box yang biasa beroperasi 24 jam mengalami penurunan omzet diatas $50 \%$.

Pemerintah Kota Bandung telah membuat kebijakan Peratuan Daerah (Perda) yang ditetapkan pada tahun 2009 yang diharapkan dapat mengatasi masalah ini, dengan menata aturan main bagi usaha mini market agat tidak mematikan para pedagang tradisional

Perda Kota Bandung No. 2 Tahun 2009 Tentang Penataan Pasar Tradisional, Pusat Perbelanjaan dan Toko Modern di Kota Bandung. menyatakan bahwa persyaratan minimarket adalah:

1. Berjarak minimal $0,5 \mathrm{~km}$ dari pasar tradisional dan $0,1 \mathrm{~km}$ dari usaha kecil sejenis yang terletak di pinggir jalan kolektor/arteri

2. Di pinggir jalan lingkungan dengan luas gerai sampai dengan $200 \mathrm{~m}$ persegi, berjarak minimal $0,5 \mathrm{~km}$ dari pasar tradisional dan usaha kecil sejenis

3. Setiap pengelola pusat perbelanjaan dan toko modern wajib melaksanakan kemitraan dengan usaha kecil

4. Kemitraan wajib dilaksanakan dalam bentuk kerjasama pemasaran, penyediaan tempat usaha, penerimaan produk dan dilaksanakan berdasarkan perjanjian tertulis dengan prinsip saling memerlukan, memperkuat dan menguntungkan

5. Waktu pelayanan dimulai pukul 10.00-22.00, kecuali ada ijin khusus dari Walikota

Bila dikaji lebih lanjut Perda tersebut telah memuat berbagai hal mengenai kebijakan operasional ritel termasuk minimarket. Yang menjadi pertanyaan adalah sejauhmana pemerintah mengimplementasikan kebijakan tersebut sehingga warung-warung tradisional dapat eksis dan bersaing.

Berdasarkan kenyataan tersebut, penulis tertarik melakukan penelitian dengan judul : Kebijakan Penataan Minimarket dan Pemberdayaan Pedagang Tradisional di Kota Bandung (Studi di Kawasan Pemukiman Kecamatan Antapani). 


\section{Perumusan Masalah}

Berdasarkan latar belakang penelitian yang telah diuraikan, maka masalah dapat dirumuskan sebagai berikut: "Penataan minimarket yang beroperasi di Kecamatan Antapani masih belum sesuai dengan Perda yang berlaku, sehingga belum dapat menciptakan pertumbuhan kehidupan usaha perdagangan yang sehat antara mini market dan pedagang tradisional, yang menyebabkan tidak sedikit pedagang yang dikatagorikan sebagai sektor ekonomi lemah ini gulung tikar. Dari perumusan masalah tersebut peneliti menjabarkan menjadi pertanyaan penelitian sebagai berikut :

"Mengapa kebijakan penataan mini market ini belum dapat diterapkan dengan baik dan bagaimana sebaiknya usaha yang dulakukan untuk memberdayakan para pedagang tradisional, khususnya yang berada di Kawasan pemukiman Kecamatan Antapani

\section{Model Pendekatan yang digunakan.}

Pendekatan yang digunakan dalam penelitian ini adalah kualitatif. Data diperoleh melalui indepth interview, observasi, studi literature dan pengumpulan data sekunder. Adapun informan pada penelitian ini adalah pejabat perijinan BPPT, Disperindag KUKM, Camat Antapani, Minimarket dan Ritel Tradisional di Kecamatan Antapani. Dengan pendekatan yang digunakan ini diharapkan dapat memberikan kontribusi dalam rangka Memberikan rekomendasi sebagai alternatif solusi implementasi kebijakan penataan pasar tradisional dan pasar modern sehingga tidak ada pihak yang dirugikan. Selain itu yang lebih penting, hasilpenelitian ini dapat emberikan rekomendasi model kemitraan minimarket dengan pedagang tradisional.

\section{HASIL PENELITIAN DAN PEMBAHASAN}

Perda Kota Bandung No. 2 Tahun 2009 yang membahas penataan pasar tradisional, pusat perbelanjaan serta toko modern di Kota Bandung merupakan sebuah jawaban dari perkembangan perekonomian khususnya perdagangan di kota Bandung, dengan harapan bahwa diterbitkan Perda tersebut akan tumbuh kepastian hukum bagi seluruh warga masyarakat kota Bandung dan juga untuk menjamin keseimbangan terhadap usaha perdagangan besar, menengah, dan kecil yang diharapkan dapat mencegah terjadinya praktik usaha yang tidak sehat.

Sesuai dengan Pasal 3 yang mengatakan bahwa setiap pedagang diberikan kebebasan dalam melakukan kegiatan perdagangannya namun dengan tetap memperhatikan nilai-nilai, etika, estetika, dan moralitas masyarakat dalam memenuhi hasrat berusahanya yang berdampak pada terpeliharanya kepentingan masyarkat, perlindungan konsumen dan lingkungan hidup. Jelas bahwa diterbitkannya Perda ini merupakan sebuah solusi yang mengedepankan kepentingan semua pihak, baik pedagang, masyarakat sebagai konsumen serta lingkungan hidup juga turut diperhatikan.

Berkaitan dengan penjagaan iklim perdagangan yang baik dan menguntungkan seluruh pihak tersebut maka diciptakan regulasi dalam kegiatan perdagangan. Regulasi-regulasi yang ditetapkan pun tercantum dalam BAB III 
Perda Kota Bandung No. 2 Tahun 2009. Regulasi yang ditetapkan mencakup segala hal yang menyangkut seluk beluk perdagangan diantaranya ialah regulasi penjualan bagi beragam kategori pedagang hingga regulasi mengenai barang yang layak diperjual-belikan. Serta membahas mengenai batasan dari persaingan usaha.

Melalui Pasal 13 Perda Kota Bandung No. 2 Tahun 2009 ditetapkan pula klasifikasi kriteria perdagangan, klasifikasi toko modern hingga klasifikasi sitem penjualan dan jenis barang dagangan. Pasal 18 hingga Pasal 20 dibahas mengenai aturan lokasi dan jarak tempat usaha perdagangan sesuai klasifikasi yang sudah ditetapkan sebelumnya. Dan berdasarkan observasi yang telah dilakukan pada ketiga pasal inilah banyak pelanggaran yang dilakukan oleh pengelola supermarket/minimarket di wilayah Antapani.

Kegiatan perdagangan yang diatur dalam Perda Kota Bandung No. 2 Tahun 2009 dilakukan pembinaan dan pengawasan oleh Pemerintah Daerah. Kegiatan pembinaan yang dimaksud diantaranya ialah pembinaan bagi pasar tradisional dalam rangka mengupayakan sumber-sumber alternatif pendanaan, pemberdayaan, hingga upaya untuk meningkatkan kompetensi pedagang dan pengelola pasar tradisional, serta tentunya melakukan evaluasi pengelolaan pasar tradisional. Sedangkan pembinaan yang diberikan kepada pusat perbelanjaan dan toko modern ialah dalam hal memberdayakan pusat perbelanjaan dan toko modern dalam membina pasar tradisional serta mengawasi kegiatan kemitraan.

Berkaitan dengan kegiatan kemitraan antara pedagang pasar tradisional dan toko modern dibahas dalam Pasal 25 hingga Pasal 27 pada Perda Kota Bandung No. 2 Tahun 2009. Beragam bentuk kemitraan yang dapat dilakukan diantaranya ialah dalam bentuk kerjasama pemasaran, penyediaan tempat usaha, penerimaan produk yang tentunya dengan prinsip saling memerlukan, memperkuat, dan menguntungkan.

Mengenai waktu operasional pelayanan ditetapkan dalam Pasal 34 Perda Kota Bandung No. 2 Tahun 2009. Berdasarkan hasil observasi dan wawancara di wilayah Antapani ditemukan bahwa hampir seluruh minimarket di kawasan ini melakukan pelanggaran dalam hal waktu operasional. Padahal dengan jelas dicantumkan bahwa waktu pelayanan yang ditetapkan untuk hari di luar hari libur ialah dimulai pukul 10.00 hingga 22.00 WIB.

Bila diteliti lebih dalam, nampak bahwa content atau isi dari pasal-pasal tersebut sudah cukup bagus, namun bagaimanakah dengan gairah target groups untuk melaksanakannya? Pertanyaan ini muncul karena salah satu target groups yaitu minimarket sering sekali melanggar ketentuan yang sudah digariskan dalam Perda No. 2 Tahun 2009 tersebut .

\section{Peran Pemerintah Daerah}

Badan-badan pelaksana yang bertanggung jawab dalam implementasi Perda Kota Bandung No. 2 Tahun 2009 adalah Pemerintah Daerah dalam hal ini ialah Pemerintah Daerah Kota Bandung khususnya Badan Pelayanan Perizinan Terpadu (BPPT) Kota Bandung dan Dinas Perindustrian, Perdagangan dan Koperasi Usaha 
Kecil Menengah (Disperindag KUKM) Kota Bandung. Selain itu yang bukan implementor secara langsung tetapi masih terkait dengan pelaksanan kebijakan ini adalah Dinas Tata Ruang dan Cipta Karya (Distarcip) Kota Bandung yang memberikan keterangan peruntukan ruang, Kecamatan dalam hal ini Kecamatan Antapani yang memberikan surat keterangan domisili dan Satuan Polisi Pamong Praja (Satpol PP) Kota Bandung sebagai aparat penegak atau penjaga pelaksanaan kebijakan. Peranan Pemerintah Provinsi Jawa Barat dan Pemerintah Daerah Kota Bandung ialah sebagai pembina dan pengawas implementasi Perda Kota Bandung No. 2 Tahun 2009.

Badan Pelayanan Perizinan Terpadu (BPPT) Kota Bandung merupakan instansi perpanjangan tangan dari Pemerintah Kota Bandung yang menerbitkan izin pendirian tempat usaha setelah sebelumnya pemohon melengkapi segala prasyarat yang ditentukan seperti Izin Usaha Toko Modern (IUTM) untuk perizinan pendirian minimarket, supermarket, department store, hypermarket, dan perkulakan. Mekanisme pelaksanaan pelayanan perizinan ini diatur lebih lanjut melalui Peraturan Walikota. Dinas Perindustrian, Perdagangan dan Koperasi Usaha Kecil Menengah Kota Bandung (Disperindag KUKM) merupakan instansi yang melakukan koordinasi bersama Badan Pelayanan Perizinan Terpadu (BPPT) Kota Bandung dalam hal menerbitkan izin pendirian tempat usaha.

Dalam pasal 22 ayat (1), menyebutkan bahwa "pasar tradisional, pusat perbelanjaan dan toko modern wajib memiliki Izin Usaha Perdagangan," Sedangkan pada ayat (2), Izin Usaha Perdagangan sebagaimana dimaksud pada ayat (1) terdiri dari:

a. "Izin Usaha Pengelolaan Pasar Tradisional (IUP2T) untuk pasar tradisional;

b. Izin Usaha Pusat Perbelanjaan (IUPP) untuk pertokoan, mall, plaza, dan pusat perdagangan;

c. Izin Usaha Toko Modern (IUTM) untuk minimarket, supermarket, Departemen store, Hypermarket dan grosir yang berbentuk perkulakan."

(Perda Kota Bandung no. 2 tahun 2009)

Izin Usaha Toko Modern (IUTM) dimaksudkan agar pertumbuhan toko modern dapat dikendalikan, karena untuk kepemilikan Izin Usaha Toko Modern (IUTM) harus memenuhi persyaratan yang telah ditentukan dalam kelayakan pengoperasian toko modern.

Dalam rangka memfasilitasi masyarakat kota Bandung dalam membuat Izin Usaha Toko Modern (IUTM), Pemerintah Kota Bandung membentuk lembaga teknis daerah yang berdasarkan Peraturan Daerah Kota Bandung Nomor 12 Tahun 2009 Tentang Perubahan Atas Peraturan Daerah Nomor 12 Tahun 2007 Tentang Pembentukan dan Susunan Organisasi Lembaga Teknis Daerah Kota Bandung yaitu Badan Pelayanan Perizinan Terpadu (BPPT) Kota Bandung. BPPT memiliki tugas pokok untuk melaksanakan koordinasi dan menyelenggaraan pelayanan administrasi di bidang perizinan secara terpadu dengan prinsip koordinasi, integrasi, sinkronisasi, simplifikasi, keamanan dan kepastian.

Berikut disajikan rincian tugas BPPT menurut Peraturan Walikota Nomor 550 Tahun 2008 Tentang Prosedur Penyelenggaraan Pelayanan Perizinan Terpadu Satu Pintu (PPTSP), sebagai berikut: 
Tabel 2. Tugas Tim Teknis Pelayanan Perizinan Terpadu Satu Pintu (PPTSP) pada BPPT Kota Bandung

\begin{tabular}{|c|c|c|}
\hline No & Jabatan & Uraian \\
\hline 1. & $\begin{array}{l}\text { Koordinator Tim Teknis Izin } \\
\text { Operasional Usaha } \\
\text { (Kepala Bidang Perizinan I I } \\
\text { (Satu) pada Badan Pelayanan } \\
\text { Perizinan Terpadu Kota } \\
\text { Bandung) }\end{array}$ & $\begin{array}{l}\text { a. Mengkoordinasikan pelaksanaan } \\
\text { pelayanan perizinan kepada tim teknis } \\
\text { sesuai dengan bidangnya; } \\
\text { b. Memfasilitasi dan melaksanakan } \\
\text { kegiatan rapat internal tim teknis; } \\
\text { c. Memberikan arahan dan petunjuk teknis } \\
\text { pelaksanaan kinerja tim teknis; }\end{array}$ \\
\hline 2. & $\begin{array}{l}\text { Anggota Tim Teknis Izin } \\
\text { Operasional Usaha } \\
\text { (Kepala Bidang } \\
\text { Perdagangan,, Kepala Seksi } \\
\text { Bimbingan Usaha dan Sarana } \\
\text { Perdagangan, Pelaksana di } \\
\text { Seksi Bimbingan Usaha dan } \\
\text { Sarana Perdagangan) }\end{array}$ & $\begin{array}{l}\text { a. Melaksanakan pemeriksaan di lapangan } \\
\text { dan membuat Berita Acara Pemeriksaan } \\
\text { serta membuat analisis/kajian teknis } \\
\text { sesuai dengan bidangnya; } \\
\text { b. Memberikan rekomendasi berupa kajian } \\
\text { teknis terhadap jenis pelayanan } \\
\text { perizinan tertentu, dengan rekomendasi } \\
\text { berupa pelulusan, penangguhan, atau } \\
\text { penolakan atas izin tertentu; } \\
\text { c. Melaksanakan monitoring dan evaluasi } \\
\text { tentang perizinan tertentu yang } \\
\text { diberikan, sesuai dengan tugas pokok } \\
\text { dan fungsi Satuan Kerja Perangkat } \\
\text { Daerah yang bersangkutan. }\end{array}$ \\
\hline
\end{tabular}

(Sumber : Peraturan Walikota Nomor 550 Tahun 2008)

BPPT melakukan kegiatan administrasi pelayanan perizinan yaitu membuat perizinan baru untuk masyarakat yang ingin mengajukan IUTM, dan tim teknis Disperindag KUKM melakukan pemeriksaan teknis danmemberikan rekomendasi sebagai kelayakan penerbitan IUTM serta memonitoring dan mengevaluasi proses perizinan, dalam hal ini maksudnya yaitu melaksanakan monitoring dan mengevaluasi IUTM yang sudah terbit sebagai umpan balik untuk mengkaji ulang IUTM yang sudah terbit.

Pemantauan dan pengawasan terhadap IUTM terbit merupakan dasar atau umpan balik bagi BPPT dan Disperindag KUKM untuk mengkaji ulang IUTM yang sudah terbit, tindakan yang dilakukan setelah melakukan kajian adalah:

1. Perizinan yang sudah sesuai aturan dapat terus diberlakukan dan di herregistrasi/diperpanjang.

2. Perizinan yang tidak sesuai dengan aturan dapat dibekukan dan dicabut izinnya setelah sebelumnya memberikan teguran.

(Sumber: Badan Pelayanan Perizinan Terpadu Kota Bandung) 
Selain dua instansi sebagai implementor kebijakan Perda No 2, tidak lupa ada peran penting yang memberikan dukungan besar terhadap kelancaran pelaksanaan dari Perda yaitu seperti yang diuraikan berikut ini:

Dinas Tata Ruang dan Cipta Karya (Distarcip) Kota Bandung ialah sebagai instansi yang mengetahui dengan baik penataan tata ruang Kota Bandung. Dinas ini mampu memberikan kepastian tepat atau tidaknya pendirian supermarket/minimarket di suatu tempat sesuai dengan peruntukannya.

Kecamatan berkontribusi dalam hal pengeluaran Surat Keterangan Domisili yang menjadi input bagi BPPT dalam mengeluarkan IUTM. Selain itu, Camat berperan dalam memberikan informasi yang up to date akan ada tidaknya pelanggaran yang terjadi selama minimarket beroperasi di wilayah kecamatan.

Satuan Polisi Pamong Praja (Satpol PP) Kota Bandung ialah sebagai instansi yang bertugas langsung menertibkan setiap pelanggaran-pelanggaran yang terjadi yang kemudian dilanjutkan kepada pihak kepolisian. Satpol PP Kota Bandung bertugas untuk menegakkan setiap aturan yang dimuat dalam Perda Kota Bandung No. 2 Tahun 2009.

Data di lapangan yang diperoleh baik melalui wawancara dan observasi, political will dari Pemerintah Daerah Kota Bandung belum terlihat dengan jelas. Hal ini terlihat dari berbagai fakta sebagai berikut:

a. Dua minimarket di Antapani yang belum mengantongi Surat Keterangan Domisili dari Kecamatan Antapani masih beroperasi sampai sekarang. Pemerintah Daerah belum melakukan tindakan tegas.

b. Pelanggaran jam operasional dan tidak melaksanakan kemitraan padahal peraturan sudah dua tahun berjalan, belum mendapatkan sanksi apa-apa dari Pemerintah Daerah

c. Secara politis bargainig power pedagang tradisional rendah, akan tetapi mereka jumlahnya banyak dan menderita penurunan omzet hingga $70 \%$. Kondisi ini membuat Pemerintah Daerah seolah-olah membiarkan kondisi berjalan begitu saja.

Berikut disajikan rekapitulasi hasil wawancara dengan peritel tradisional di Kecamatan Antapani: 
Sosiohumaniora, Volume 13, No. 2, Juli 2011 : 140 - 159

\begin{tabular}{|c|c|c|c|c|c|c|c|}
\hline $\begin{array}{l}\mathbf{N} \\
\mathbf{0}\end{array}$ & $\begin{array}{l}\text { Item } \\
\text { Inter } \\
\text { view }\end{array}$ & $\begin{array}{c}\text { Antapani } \\
\text { Wetan } \\
\text { Warung AK } \\
\text { (Cikadut) }\end{array}$ & $\begin{array}{c}\text { Antapani } \\
\text { Tengah } \\
\text { Toko Ar } \\
\text { Jl. Kuningan } \\
\text { Raya }\end{array}$ & $\begin{array}{c}\text { Antapani } \\
\text { Kidul } \\
\text { Toko K } \\
\text { (Jl } \\
\text { Purwakarta) }\end{array}$ & $\begin{array}{c}\text { Antapani } \\
\text { Kulon Kios T } \\
\text { (Jl. Jakarta } \\
\text { Timur) }\end{array}$ & $\begin{array}{c}\text { Pasar Antasari } \\
\text { Kios E dan } \\
\text { Kios A }\end{array}$ & Keterangan \\
\hline 1 & Jarak & $\begin{array}{l}30 \text { m dengan } \\
\text { Griyamart JI } \\
\text { AH Nasution }\end{array}$ & $\begin{array}{l}12 \text { m dengan } \\
\text { Alfamart Jl } \\
\text { Kuningan dan } \\
20 \text { m dengan } \\
\text { Indomaret Jl } \\
\text { Terusan } \\
\text { Jakarta }\end{array}$ & $\begin{array}{l}40 \text { meter } \\
\text { dengan } \\
\text { Yomart Jalan } \\
\text { Purwakarta. }\end{array}$ & $\begin{array}{l}100 \text { m dengan } \\
\text { Alfamart dan } \\
20 \text { m dengan } \\
\text { Superindo }\end{array}$ & $\begin{array}{l}\text { Duaduanya } \\
\text { sekitar } 400 \mathrm{~m} \\
\text { dengan Alfamart } \\
\text { Jl Antapani dan } \\
500 \mathrm{~m} \text { dengan } \\
\text { Superindo }\end{array}$ & $\begin{array}{l}\text { Pada } \\
\text { umumnya } \\
\text { warung } \\
\text { tradisional } \\
\text { merasa } \\
\text { terganggu } \\
\text { karena jarak } \\
\text { yang } \\
\text { berdekatan } \\
\text { dengan } \\
\text { minimarket } \\
\text { dan jumlahnya } \\
\text { sangat banyak } \\
\text { di Antapani. }\end{array}$ \\
\hline 2 & Omzet & $\begin{array}{l}\text { Berdiri tahun } \\
2008 \text { dan } \\
\text { biasanya } \\
\text { memperoleh } \\
\text { omzet 3juta } \\
\text { per bulan. } \\
\text { Setelah ada } \\
\text { minimarket } \\
\text { turun menjadi } \\
1,5-2 \text { juta } \\
\text { rupiah atau } \\
\text { turun sekitar } \\
35-50 \%\end{array}$ & $\begin{array}{l}\text { Berdiri sejak } \\
\text { Tahun } 2006 . \\
\text { Omsetnya } \\
\text { sebelum ada } \\
\text { minimarket } \\
\text { terdekat } \\
\text { sekitar Rp. } \\
100.000 \\
\text { hingga Rp. } \\
200.000 \\
\text { perhari. Kini } \\
\text { omsetnya } \\
\text { anjlok menjadi } \\
\text { Rp. } 25.000 \\
\text { hingga Rp. } \\
50.000 \text { per } \\
\text { hari. Atau } \\
\text { turun sekitar } \\
75 \% \text {. } \\
\end{array}$ & $\begin{array}{l}\text { Berdiri sejak } \\
\text { 2003. Omzet } \\
\text { biasanya Rp. } \\
500.000- \\
\text { Rp.700.000 } \\
\text { perhari namun } \\
\text { kini sekitar } \\
\text { Rp.50.000- } \\
\text { Rp. } 200.000 \\
\text { atau menurun } \\
\text { sekitar } 70- \\
90 \% .\end{array}$ & $\begin{array}{l}\text { Berdiri sejak } \\
2004 \text {. Omzet } \\
\text { dulu Rp. } 2 \text { juta } \\
\text { sekarang } \\
\text { hanya } 1-1,5 \\
\text { juta per hari, } \\
\text { menurun } \\
\text { sekitar } 25- \\
50 \% \text {. }\end{array}$ & $\begin{array}{l}\text { Berdiri sejak } \\
2005 \text { Kios E } \\
\text { biasanya omzet } \\
\text { 2-3 juta per hati } \\
\text { sekarang } \\
\text { menjadi 0,7-1,5 } \\
\text { juta per hari } \\
\text { atau turun } \\
\text { sekitar 50- 70\% } \\
\text { Berdiri sejak } \\
\text { 2005, Kios A } \\
\text { omsetnya 0,9-1 } \\
\text { juta rupiah per } \\
\text { hari namun kini } \\
\text { hanya 0,2-0,3 } \\
\text { juta rupiah } \\
\text { perharinya. Atau } \\
\text { turun lebih dari } \\
\text { 70\%. }\end{array}$ & $\begin{array}{l}\text { Secara umum } \\
\text { warung } \\
\text { tradisional } \\
\text { baik yang } \\
\text { berada di } \\
\text { pasar maupun } \\
\text { di luar pasar } \\
\text { mengalami } \\
\text { penurunan } \\
\text { yang } \\
\text { signifikan } \\
\text { mencapai } \\
70 \%\end{array}$ \\
\hline 3 & $\begin{array}{l}\text { Peme } \\
\text { rintah }\end{array}$ & $\begin{array}{l}\text { Walaupun } \\
\text { omset warung } \\
\text { tradisional } \\
\text { menurun, } \\
\text { tidak ada } \\
\text { perhatian dari } \\
\text { pemerintah. } \\
\text { Namun } \\
\text { merasa } \\
\text { berterimakasih } \\
\text { diijinkan buka } \\
\text { di pinggir jalan } \\
\text { walaupun } \\
\text { mengganggu } \\
\text { pejalan kaki. }\end{array}$ & $\begin{array}{l}\text { Belum ada } \\
\text { kepedulian } \\
\text { pemerintah } \\
\text { akan warung } \\
\text { tradisional. } \\
\text { Menurut } \\
\text { pemilik, } \\
\text { pemerintah } \\
\text { tidak adil, } \\
\text { karena tidak } \\
\text { memperhatika } \\
\text { n pedagang } \\
\text { kecil, buktinya } \\
\text { minimarket } \\
\text { sampai } \\
\text { banyak } \\
\text { berdiri. }\end{array}$ & $\begin{array}{l}\text { Pemerintah } \\
\text { kurang } \\
\text { memperhatika } \\
\text { n. Tempat } \\
\text { usaha } \\
\text { dibuatkan } \\
\text { kelurahan dulu } \\
\text { Cuma-Cuma } \\
\text { tetapi } \\
\text { sekarang } \\
\text { bayar Rp. } \\
200.000 \text { per } \\
\text { tahun. }\end{array}$ & $\begin{array}{l}\text { Tidak ada } \\
\text { sama sekali, } \\
\text { DUlu pernah } \\
\text { di data untuk } \\
\text { bantuan } \\
\text { modal tetapi } \\
\text { realisasinya } \\
\text { tidak ada. }\end{array}$ & $\begin{array}{l}\text { Pasar Antasari } \\
\text { dibangun atas } \\
\text { inisiatif para } \\
\text { pedagang, } \\
\text { kemudian } \\
\text { Kelurahan dan } \\
\text { kecamatan } \\
\text { member ijin. } \\
\text { Sebenarnya ini } \\
\text { tanah kosong } \\
\text { yang } \\
\text { disengketakan } \\
\text { (ada sebelas } \\
\text { orang yang } \\
\text { mengaku } \\
\text { pemiliknya). } \\
\text { Selama sengketa } \\
\text { kelurahan } \\
\text { mengijinkan } \\
\text { asalkan menjaga } \\
\text { K3. Wakil } \\
\text { Walikota juga } \\
\text { masih }\end{array}$ & $\begin{array}{l}\text { Warung } \\
\text { tradisional } \\
\text { mengeluhkan } \\
\text { kekurangpedul } \\
\text { ian } \\
\text { pemerintah } \\
\text { akan turunnya } \\
\text { omset akibat } \\
\text { banyak } \\
\text { berdirinya } \\
\text { minimarket }\end{array}$ \\
\hline
\end{tabular}


Kebijakan Penataan Minimarket dan Pemberdayaan Pedagang Tradisional di Kota Bandung: Studi di Kawasan Pemukiman Kecamatan Antapani (Budiman Rusli)

\begin{tabular}{|c|c|c|c|c|c|c|c|}
\hline $\begin{array}{l}\mathbf{N} \\
\mathbf{0}\end{array}$ & $\begin{array}{l}\text { Item } \\
\text { Inter } \\
\text { view }\end{array}$ & $\begin{array}{c}\text { Antapani } \\
\text { Wetan } \\
\text { Warung AK } \\
\text { (Cikadut) }\end{array}$ & $\begin{array}{c}\text { Antapani } \\
\text { Tengah } \\
\text { Toko Ar } \\
\text { Jl. Kuningan } \\
\text { Raya }\end{array}$ & $\begin{array}{c}\text { Antapani } \\
\text { Kidul } \\
\text { Toko K } \\
\text { (Jl } \\
\text { Purwakarta) }\end{array}$ & $\begin{array}{c}\text { Antapani } \\
\text { Kulon Kios T } \\
\text { (Jl. Jakarta } \\
\text { Timur) }\end{array}$ & $\begin{array}{c}\text { Pasar Antasari } \\
\text { Kios E dan } \\
\text { Kios A }\end{array}$ & Keterangan \\
\hline & & & & & & $\begin{array}{l}\text { mengijinkan } \\
\text { sampai tanah ini } \\
\text { jelas siapa } \\
\text { pemiliknya. }\end{array}$ & \\
\hline 4 & $\begin{array}{l}\text { Pelangg } \\
\text { aran }\end{array}$ & $\begin{array}{l}\text { Griyamart } \\
\text { buka dari jam } \\
08.00 \text { dan } \\
\text { tutup jam } \\
22.00\end{array}$ & $\begin{array}{l}\text { Jam buka } \\
\text { biasanya jam } \\
6 \text { pagi dan } \\
\text { tutup jam } 12 \\
\text { malam }\end{array}$ & $\begin{array}{l}\text { Jam buka } \\
\text { Yomart 08.00- } \\
22.00\end{array}$ & $\begin{array}{l}\text { Buka jam } \\
08.00 \text { tutup } \\
\text { jam } 22.00\end{array}$ & $\begin{array}{l}\text { Buka jam } 8 \\
\text { tutup jam } 10 \\
\text { malam }\end{array}$ & $\begin{array}{l}\text { Beberapa } \\
\text { minimarket } \\
\text { melebihi } \\
\text { ketentuan jam } \\
\text { operasional }\end{array}$ \\
\hline 5 & $\begin{array}{l}\text { Kemitra } \\
\text { an }\end{array}$ & $\begin{array}{l}\text { Tidak pernah } \\
\text { diajak } \\
\text { bermitra oleh } \\
\text { minimarket } \\
\text { terdekat }\end{array}$ & $\begin{array}{l}\text { Tidak ada } \\
\text { kerjasama }\end{array}$ & $\begin{array}{l}\text { Tidak pernah } \\
\text { ada yang } \\
\text { mengajak } \\
\text { kerjasama }\end{array}$ & $\begin{array}{l}\text { Tidak pernah } \\
\text { ada. Bahkan } \\
\text { ketika buka } \\
\text { tidak ada ijin- } \\
\text { ijin Ikepada } \\
\text { warung=waru } \\
\text { ng seperti } \\
\text { saya }\end{array}$ & $\begin{array}{l}\text { Tidak pernah } \\
\text { ada kerjasama }\end{array}$ & $\begin{array}{l}\text { Menurut para } \\
\text { pemilik } \\
\text { warung } \\
\text { tradisional, } \\
\text { selama ini } \\
\text { tidak ada } \\
\text { kerjasama } \\
\text { dengan } \\
\text { minimarket } \\
\text { baik modal, } \\
\text { pelatihan } \\
\text { maupun } \\
\text { pasokan } \\
\text { barang. } \\
\end{array}$ \\
\hline 6 & $\begin{array}{l}\text { Harapa } \\
\text { n }\end{array}$ & $\begin{array}{l}\text { Jangan } \\
\text { memainkan } \\
\text { harga } \\
\text { misalkan yang } \\
\text { Rp. } 1000 \text { jadi } \\
\text { Rp.1.025, } \\
\text { sehingga } \\
\text { masyarakat } \\
\text { jadi punya } \\
\text { kesan harga } \\
\text { sama saja, } \\
\text { mending beli } \\
\text { di minimarket } \\
\text { lebih nyaman. } \\
\text { Selain itu } \\
\text { ajaklah kami } \\
\text { bermitra biar } \\
\text { saling } \\
\text { menguntungk } \\
\text { an. Kalau } \\
\text { tidak, ya jual } \\
\text { barang ke } \\
\text { warung- } \\
\text { warung lebih } \\
\text { dimurahkan. }\end{array}$ & $\begin{array}{l}\text { Batasi jam } \\
\text { operasi } \\
\text { minimarket, } \\
\text { batasi } \\
\text { pendirian } \\
\text { minimarket, } \\
\text { harga di } \\
\text { minimarket } \\
\text { sebaiknya } \\
\text { sama atau } \\
\text { bahkan lebih } \\
\text { mahal dari } \\
\text { warung } \\
\text { tradisional. } \\
\text { Sebaiknya ada } \\
\text { bantuan } \\
\text { modal dan } \\
\text { pelatihan } \\
\text { usaha. }\end{array}$ & $\begin{array}{l}\text { Kalau bias } \\
\text { harga di } \\
\text { Yomart lebih } \\
\text { mahal agar } \\
\text { tidak } \\
\text { membanting } \\
\text { harga warung } \\
\text { Jangan terlalu } \\
\text { banyak } \\
\text { membangun } \\
\text { minimarket } \\
\text { Ada bantuan } \\
\text { modal dan } \\
\text { pengembanga } \\
\mathrm{n} \text { usaha }\end{array}$ & $\begin{array}{l}\text { Jangan } \\
\text { samapai } \\
\text { menjatuhkan } \\
\text { kami yang } \\
\text { buka warung } \\
\text { karena } \\
\text { harganya } \\
\text { terlalu murah. } \\
\text { Dan jarakntya } \\
\text { terlalu dekat } \\
\text { dengan } \\
\text { warung=waru } \\
\text { ng. }\end{array}$ & $\begin{array}{l}\text { Pemerintah } \\
\text { kalau member } \\
\text { ijin pendirian } \\
\text { minimarket } \\
\text { jangan dekat- } \\
\text { dekat dengan } \\
\text { warung. } \\
\text { Kalau tanah } \\
\text { pasar diambil } \\
\text { pemiliknya } \\
\text { mohon ada } \\
\text { gantinya karena } \\
\text { di Antapani tidak } \\
\text { ada pasar lagi. }\end{array}$ & $\begin{array}{l}\text { Para pemilik } \\
\text { warung } \\
\text { tradisional } \\
\text { berharap } \\
\text { pemerintah } \\
\text { peduli pada } \\
\text { warung } \\
\text { tradisional, } \\
\text { membatasi } \\
\text { pendirian } \\
\text { minimarket, } \\
\text { jam operasi } \\
\text { minimarket } \\
\text { dan berharap } \\
\text { minimarket } \\
\text { tidak terlalu } \\
\text { murah } \\
\text { menetapkan } \\
\text { harga. }\end{array}$ \\
\hline
\end{tabular}

\section{Keberadaan Mini Market di Kecamatan Antapani.}

Perda Kota Bandung No. 2 Tahun 2009 ditujukan kepada pengelola pusat perbelanjaan toko modern maupun pasar tradisional, sesuai yang tertuang dalam Pasal 16, yang diharapkan mampu mengadopsi pola-pola interaksi yang tercantum dalam peraturan daerah tersebut. Di Kecamatan Antapani target groups yang terkait dengan Perda Kota Bandung No. 2 Tahun 2009 ialah supermarket maupun 
minimarket dan warung. Tercatat terdapat 16 minimarket dan ribuan warung tradisional di wilayah Kecamatan Antapani. Berikut ini minimarket yang berada di wilayah Kecamatan Antapani.

Tabel 4. Minimarket Di Wilayah Kecamatan Antapani

\begin{tabular}{|c|c|c|c|}
\hline NO. & KELURAHAN & $\begin{array}{l}\text { NAMA } \\
\text { MINIMARKET }\end{array}$ & ALAMAT \\
\hline 1. & \multirow{3}{*}{$\begin{array}{l}\text { Antapani } \\
\text { Wetan }\end{array}$} & Alfamart & JL. Tanjungsari \\
\hline 2. & & Indomart & JL. Terusan Jakarta \\
\hline 3. & & Griya Mart & JL. A.H. Nasution \\
\hline 4. & \multirow{2}{*}{ Antapani Kulon } & Alfamart * & JL. Antapani \\
\hline 5. & & Indomart & JL. Terusan Jakarta \\
\hline 6 & \multirow{6}{*}{$\begin{array}{l}\text { Antapani } \\
\text { Tengah }\end{array}$} & Alfamart & JL. Parakan Saat \\
\hline 7 & & Alfamart & JL. Kuningan \\
\hline 8 & & Indomart & JL. Terusan Jakarta \\
\hline 9 & & SB Mart * & JL. Cibatu \\
\hline 10 & & Yomart & JL. Parakan Saat \\
\hline 11 & & Yomart & JL. Kuningan \\
\hline 12 & \multirow{5}{*}{ Antapani Kidul } & Alfamart & JL. Indramayu \\
\hline 13 & & Indomart & JL. Indramayu \\
\hline 14 & & Indomart & JL. Karang Asem \\
\hline 15 & & Griya & JL. Purwakarta \\
\hline 16 & & Yomart & JL. Purwakarta \\
\hline
\end{tabular}

Sumber: Kantor Kecamatan Antapani, 2011

Berdasarkan tabel di atas dapat diketahui bahwa di wilayah Kecamatan Antapani terdapat 16 minimarket. Wilayah yang memiliki toko modern terbanyak ialah di wilayah Kelurahan Antapani Tengah yaitu sebanyak 6 (enam) minimarket.

Berdasarkan wawancara yang dilakukan peneliti terdapat dua minimarket yaitu Alfamart yang berada di JL. Antapani dan SB Mart yang berada di JL. Cibatu, diberi tanda bintang $\left({ }^{*}\right)$, yang ternyata belum mengantongi surat keterangan domisili dari kantor kecamatan Antapani namun menurut Camat Antapani minimarket tersebut akhirnya beroperasi dan hingga kini masih terus beroperasi. Pelaporan ilegalnya operasi minimarket tersebut pun sudah dilakukan kepada pihak-pihak yang berkewenangan melakukan penertiban namun hingga kini belum ada tindak lanjut.

Dalam hal ini menurut Camat Antapani, memang Kecamatan tidak berwenang mengeluarkan ijin pendirian minimarket namun surat keterangan domisili adalah salah satu syarat pengajuan ijin ke BPPT, namun entah mengapa akhirnya tetap beroperasi.

Berdasarkan data dari persatuan warung dan pasar tradisional (Pesat), bahwa ada 133 minimarket di Kota Bandung tidak memiliki ijin (Gresnews, 2009). 
Berdasarkan data tersebut, menunjukkan bahwa kebijakan yang terkandung dalam Perda No 2 Tahun 2009 belum terlaksana dengan baik. Hal ini terbukti munculnya fakta yang menunjukkan bahwa target groups yang dalam hal ini minimarket masih banyak yang tidak taat terhadap kebijakan penataan pasar tradisional, pusat perbelanjaan dan toko modern yang diberlakukan pemerintah kota Bandung sejak tahun 2009.

Otomatis target atau sasaran penataan lainnya yaitu pedagang ritel atau warung tradisional juga terkena dampaknya. Warung tradisional yang sejatinya terfasilitasi dengan adanya perda ini, malah menjadi terpojok posisinya karena pelaksanaan perda ini belum dapat dipenuhi oleh salah satu target groups yang lain yaitu minimarket.

Gaya hidup modern yang menyukai aspek kepraktisan menjadikan minimarket maupun supermarket kian digandrungi masyarakat kota Bandung. Hal tersebut jelas saja mendukung tumbuh suburnya supermarket maupun minimarket di kota Bandung juga di wilayah Antapani Bandung.

Berbelanja di minimarket maupun supermarket memang menjadi bagian dari budaya masyarakat saat ini. Kepastian tersedianya produk-produk pemenuh kebutuhan sehari-hari, tempat berbelanja yang nyaman, pelayanan yang prima, serta aneka promo berbelanja menjadi daya pikat yang ampuh menarik minat konsumen untuk berbelanja dan kembali berbelanja lagi di supermarket/minimarket.

Meningkatnya pertumbuhan supermarket/minimarket berkorelasi dengan menurunnya daya saing toko/warung tradisional. Berdasarkan data yang diperoleh dari Asosiasi Pedagang Pasar Tradisional (APPTI), yang dikutip dari www.ekonomi.kompasiana.com, menyebutkan bahwa keberadaan minimarket modern dianggap telah menyedot pembeli yang biasa berbelanja di warung tradisional. APPTI pun menyebutkan bahwa setiap pendirian satu minimarket akan membunuh sekitar 20 pedagang tradisional.

Meskipun begitu bagaimanapun keputusan hendak kemana masyarakat akan berbelanja adalah ada pada pribadi masyarakat itu sendiri. Masyarakat memang memiliki bargaining power yang kuat dalam hal memutuskan hendak kemana mereka akan berbelanja. Dan masyarakat pun tentunya merasa dimudahkan dengan merebaknya supermarket/minimarket ini karena dapat dengan mudah mencari barang-barang untuk memenuhi kebutuhan sehari-hari, meskipun disisi lain toko/warung tradisional semakin 'tergilas' berada di situasi seperti ini.

Berdasarkan hasil observasi dan wawancara yang dilakukan tim peneliti, diperoleh informasi bahwa hal dominan yang menyebabkan masyarakat modern menyukai belanja di minimarket adalah kebersihan, kenyamanan, kelengkapan dan kepastian harga. Sebaliknya, di pedagang/warung tradisonal kondisinya sangat berlawanan. Tentu saja gaya hidup masyarakat yang semakin modern ini memiliki dampak terhadap implementasi kebijakan penataan pasar diantaranya: Masyarakat semakin asyik menikmati fasilitas toko modern, sehingga tidak terlalu peduli terhadap pelanggaran yang dilakukan oleh toko modern. Sehingga laporanlaporan pelanggaran seringkali hanya muncul dari warung tradisional. Selain itu, 
misalnya banyak minimarket di Antapani yang melebihi jam buka, masyarakat malah menikmatinya ketimbang melaporkannya kepada pihak berwenang.

Gotong royong yang seyogyanya menjadi nilai kebersamaan, ternyata semakin pudar. Sejatinya toko modern membantu warung tradisional dalam bentuk kerjasama yang saling menguntungkan. Akan tetapi walaupun sudah diatur secara hukum untuk menjalin kemitraan namun perilaku individualis

atau"masing-masing" masih terlalu kuat sehingga sulit sekali mengimplementasikan program kemitraan ini

\section{Kondisi Pedagang Tradisional Di Kecamatan Antapani}

Keberadaan minimarket di wilayah Kecamatan Antapani sangat tidak menguntungkan bagi para pemilik toko/warung tradisional di sekitarnya. Toko dan warung tradisional kalah bersaing dengan minimarket tersebut. Berdasarkan wawancara yang peneliti lakukan mayoritas para pedagang mengalami penurunan omzet, bahkan ada yang mengalami penurunan omzet penjualan hingga lebih dari $70 \%$.

Terdapat banyak hal yang menyebabkan toko/warung tradisional kalah dalam persaingan dan hal tersebut juga terkait dengan pelanggaran terhadap implementasi Perda Kota Bandung No. 2 Tahun 2009 Tentang Penataan Pasar Tradisional, Pusat Perbelanjaan dan Toko Modern di Kota Bandung.

Pertama, ialah mengenai jarak lokasi keberadaan minimarket dan toko/warung tradisional.

Berdasarkan Perda Kota Bandung No. 2 Tahun 2009 Pasal 20 ditetapkan bahwa jarak antara minimarket dan usaha kecil sejenis adalah $0,5 \mathrm{~km}$ sedangkan untuk supermarket ialah $1,5 \mathrm{~km}$, namun yang terjadi adalah minimarket hanya berjarak tidak lebih dari $50 \mathrm{~m}$ dari toko/warung tradisional, dan keberadaan toko/warung tersebut sudah lebih dulu berdiri dibanding minimarket/supermarket. Berdasarkan observasi yang dilakukan di kawasan Antapani Tengah, Toko Artita yang sudah lebih dahulu berdiri (tahun 2006) diapit oleh dua minimarket, Alfamart dan Indomart, yang berjarak tidak lebih dari $20 \mathrm{~m}$. Hal yang serupa pun terjadi di kawasan Antapani Kulon. Jarak antara Toko Bapak Tardi hanya berjarak \pm 20 meter dengan Superindo, padahal Toko Bapak Tardi sudah lebih dahulu berdiri daripada Superindo.

Kelengkapan produk, harga, dan kenyamanan berbelanja memang menjadikan konsumen lebih memilih berbelanja di minimarket terutama jika antara toko tradisional dan minimarket berjarak tidak berjauhan. Toko tradisional pun semakin berkurang peminatnya yang berimbas kepada berkurangnya omzet penjualan.

Dalam Perda Kota Bandung No. 2 Tahun 2009 Pasal 25 disebutkan bahwa setiap pengelola pusat perbelanjaan dan toko modern wajib melaksanakan kemitraan dengan usaha kecil. Kemitraan yang dimaksud pun dipaparkan secara cukup jelas dalam Perda tersebut. Namun berdasarkan observasi dan juga wawancara yang peneliti lakukan hingga saat observasi dan wawancara dilakukan 
tidak pernah ada bentuk kemitraan yang dilakukan oleh pihak supermarket ataupun minimarket di kawasan Kecamatan Antapani. Meskipun memang pada beberapa minimarket ada yang memberikan sedikit lahanya untuk digunakan dengan sistem sewa.

Kedua, yang menyebabkan toko/warung tradisional kalah dalam persaingan ialah mengenai waktu beroperasi minimarket/supermarket yang berada di kawasan Antapani. Berdasarkan observasi dan wawancara yang dilakukan mayoritas minimarket dan supermarket tersebut buka lebih awal dari waktu yang ditetapkan yaitu pukul 10.00 dan tutup lebih lama dari waktu yang telah ditetapakan yaitu pukul 22.00, Perda Kota Bandung No. 2 Tahun 2009 Pasal 34. Mayoritas supermarket dan minimarket di kawasan Antapani sudah mulai beroperasi sejak pukul 08.00 pagi dan masih beroperasi pada pukul 22.00. Tentunya lama waktu beroperasi pun menjadikan semakin banyaknya konsumen yang dapat dilayani.

Pengawasan terhadap implementasi Perda Kota Bandung No. 2 Tahun 2009 ini pun dirasa kurang meskipun pihak kecamatan sudah pernah mengadukan kepada pihak-pihak yang berwenang dalam hal pelanggaran PERDA ini. Lambannya antisipasi dan tindak lanjut pemerintah setempat membuat toko/warung tradisional semakin kehilangan daya saingnya. Ditambah lagi dengan preferensi masyarakat yang memang berpihak kepada minimarket dan juga supermarket.

Sebaiknya pemerintah bukan hanya sekedar mengesahkan saja keberadaan Perda Kota Bandung No. 2 Tahun 2009 ini melainkan perlu untuk terus dilakukan pengawasan terhadap implementasinya di lapangan agar seluruh pihak diuntungkan, tidak hanya pihak bermodal besar saja. Jika memang pemerintah sudah melaksanakan perlindungan, namun ternyata bukti konkretnya tidak pernah dirasakan sama sekali oleh pihak-pihak terkait khususnya pengelola toko/warung tradisional.

\section{Model Kemitraan MRT (Minimarket-Ritel Tradisional)}

Perda No.2 tahun 2009 telah mewajibkan semua minimarket untuk melakukan kemitraan dengan usaha kecil setempat. Namun pada kenyataannya hal ini masih jauh dari harapan. Selama ini minimarket hanya menerima sebagian kecil pasokan produk UKM itu pun di drop dari gudang pusat bukan dari usaha kecil setempat. Selain itu bentuk lain kemitraan hanya berupa sewa tempat di depan gerai minimarket itu pun dengan sewa yang cukup mahal per bulannya.

Tim peneliti mengajukan model kemitraan seperti yang terlihat pada gambar 4.1. Pada gambar tersebut minimarket berperan sebagai mitra ritel tradisional melalui pelatihan, pemasok barang dengan harga grosiran. Minimarket memiliki jaringan supplier yang sangat kuat sehingga mampu mendapatkan harga termurah. Selain itu juga peritel tradisional yang memiliki barang teryentu atau memiliki keunikan dapat menitipkannya di minimarket. Selain itu minimarket juga dapat menjadi sponsor kios-kios tradisional dengan cara membangun atau merenovasi kios-kios tradisional yang sudah ada.

Pemerintah berperan sebagai fasilitator dan regulator dalam rangka mendukung efektivitas kemitraan. Pemerintah juga dapat menjadi stimulator atau 
pemberi rangsangan kemitraan yang efektif. Misalnya minimarket yang aktif bermitra akan mendapatkan insentif dari pemerintah dan juga sebaliknya yang tidak mau bermitra maka punishment akan diberlakukan sesuai peraturan yang berlaku.

Melalui pola kemitraan seperti ini baik peritel modern maupun tradisional akan sama-sama bersaing secara sehat dan adil dalam rangka menarik minat beli masyarakat atau konsumen. Dengan sendirinya akan tercipta lingkungan usaha eceran (bisnis ritel) yang kondusif dan menguntungkan semua stakeholders.

Model kemitraan ini akan memunculkan pola baru bahkan nilai-nilai baru yang diharapkan akan menjadi budaya bisnis yang sesuai dengan nilai-nilai kebangsaan dan perekonomian yang berkerakyatan. Melalui budaya bisnis ritel dengan model seperti ini akan menciptakan simbiosis mutualisma semua stakeholders baik pemerintah, pengusaha ritel modern, pengusaha ritel tradisional dan masyarakat luas.

Uraian model "Kemitraan Minimarket - Ritel Tradisional," yang telah disebutkan terangkum dalam model yang disajikan pada gambar 1. Penulis kemudian memberikan nama model ini dengan Model Kemitraan MRT.

Model Kemitraan MRT ini diharapkan akan memuluskan implementasi kebijakan penataan pasar tradisional, pusat perbelanjaan dan toko Modern di Antapani dan Kota Bandung pada umumnya. Penerapan kebijakan terhadap target groups akan hanya impian apabila target groups tersebut tidak menjalin silaturahmi melalui kemitraan usaha. Tanpa bermitra maka akan selalu terjadi friksi yang berdampak pada sulitnya mengimplementasikan Perda Nomor 2 Tahun 2009 tentang Penataan Pasar Tradisional, Pusat Perbelanjaan dan Toko Modern di Kota Bandung. 


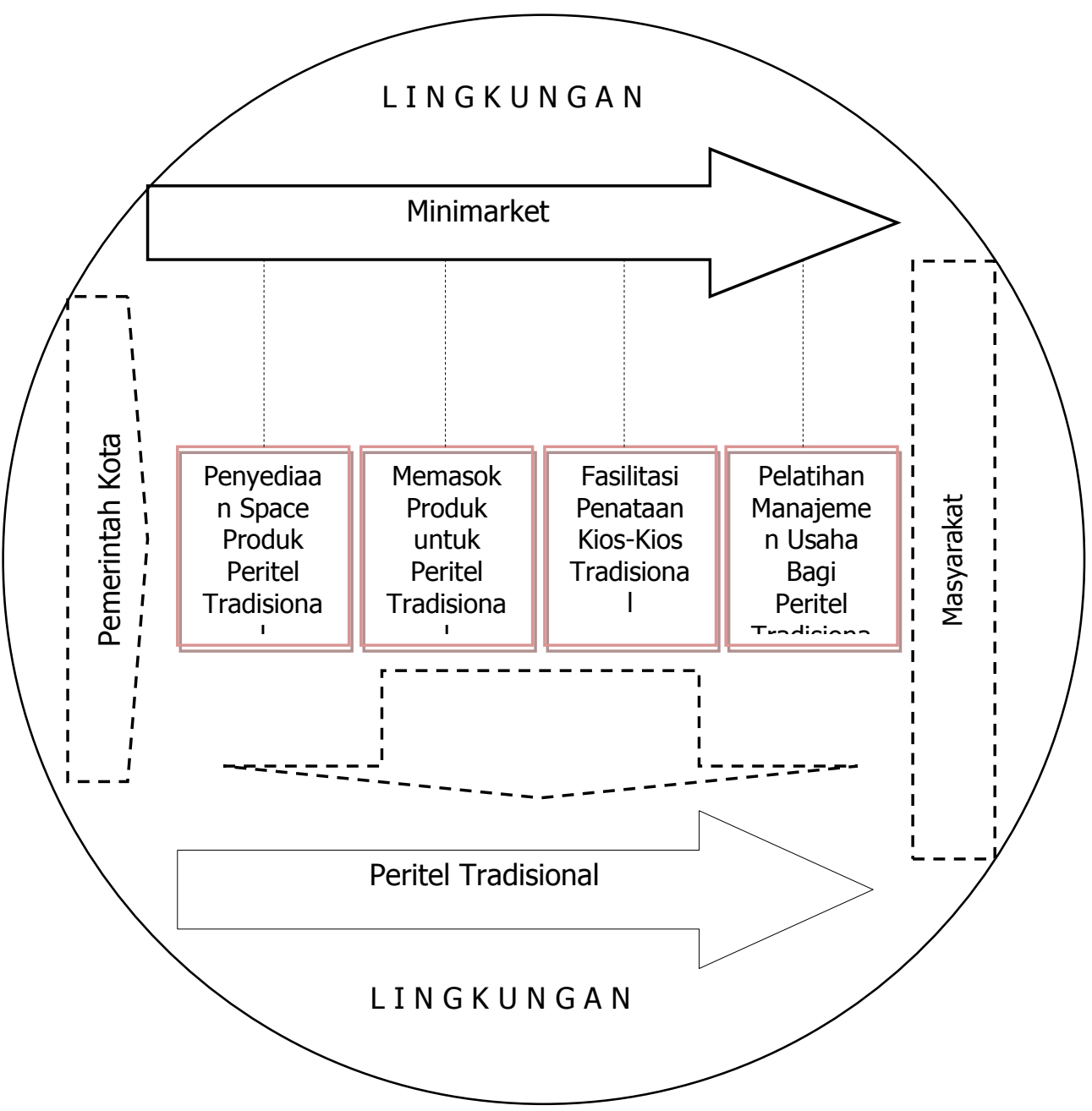

Gambar 1. Model Kemitraan MRT

\section{KESIMPULAN DAN REKOMENDASI}

\section{Kesimpulan}

Berdasarkan hasil penelitian, dapat disimpulkan bahwa Kebijakan Penataan minimarket belum berjalan sesuai dengan harapan, masih banyak pelanggaran yang ditemukan yang memunculkan dominasi dalam usaha perdagangan yang menyebabkan pedagang tradisional terpuruk. Secara detail temuan tersebut dapat dilihat dari fakta sebagai berikut:

a. Dua minimarket di Antapani yang belum mengantongi Surat Keterangan Domisili dari Kecamatan Antapani masih beroperasi sampai sekarang. Pemerintah daerah belum melakukan tindakan tegas. 
b. Pelanggaran jam operasional dan tidak melaksanakan kemitraan padahal peraturan sudah dua tahun berjalan, belum mendapatkan sanksi apa-apa dari pihak Pemerintah Daerah

c. Secara politis bargainig power pedagang tradisional rendah, akan tetapi mereka jumlahnya banyak dan menderita penurunan omzet hingga $70 \%$. Sehingga kondisi ini membuat Pemerintah Daerah seolah-olah membiarkan kondisi berjalan begitu saja.

Selanjutnya penulis menyimpulkan bahwa daya saing dari pedagang tradisional rendah. Hal ini terlihat dari penurunan omzet yang sangat tajam melampaui angka $70 \%$ setelah menjamurnya minimarket di Antapani.

Dari hasil penelitian di lapangan, penulis menemukan salah satu poin penting dalam mendukung pelaksanaan kebijakan ini melalui memperkuat pola kemitraan. Model kemitraan yang kuat akan menjadi penopang untuk memberdayakan para pedagang tradisional.

\section{Rekomendasi}

Berdasarkan penelitian yang dilakukan tim, paling tidak ada 3 (tiga) rekomendasi terkait dengan implementasi kebijakan yang termuat dalam Perda Kota Bandung No. 2 Tahun 2009:

1. Sebaiknya pemerintah melakukan evaluasi secara cermat mengenai implementasi Perda ini, segera menindak lanjuti setiap pelanggaran dan menertibkan oknum-oknum yang melanggar ketentuan yang sudah ditetapkan. Sehingga tidak ada lagi ketidak-selarasan informasi antara yang diadukan masyarakat dan yang diterima pemerintah.

2. Meningkatkan kemampuan analisis lingkungan sebagai faktor yang dapat mendorong dan menghambat implementasi kebijakan

3. Meningkatkan program pemberdayaan pedagang tradisional dengan merealisasikan keharmonisan hubungan antara pengusaha mini market dan pedagang tradisional dengan menerapakan Model Kemitraan MRT. Melalui model ini semua pihak akan menjalankan aktivitasnya dengan baik dalam situasi lingkungan bisnis ritel yang kondusif.

\section{DAFTAR PUSTAKA}

Anderson, J.E. 1979. Public Policy Making: An Introduction, $3^{\text {rd }}$ ed. Boston: Houghton Mifflin Company

Bromley, Daniel W. 1989. Economic Interest and Institutions: The Conceptual Foundations of Public Policy. New York: Basil Blackwell Ltd.

Cheema,G. Shabbir dan Dennis A. Rondinelli. 1983. Decentralization and Development, Policy Implementation in Developing Countries, (Ed). California : Sage Publications, Inc. Beverly Hills. 
Kebijakan Penataan Minimarket dan Pemberdayaan Pedagang Tradisional di Kota Bandung: Studi di Kawasan Pemukiman Kecamatan Antapani (Budiman Rusli)

Dunn, William N. 1994. Public Policy Analysis: An Introduction. New Jersey: Prentice-Hall International, Inc, Englewood Cliffs.

Dye, Thomas R. 1981. Understanding Public Policy. Englewood Cliffs: Prentice-Hall, Inc.

Edwards III, George C. 1980. Implementing Public Policy. Washington: Congressional Quarterly Inc.

Grindle, M.S. \& John W. Thomas. 1980. Public Choises and Policy Change: The Political Economy of Reform in Develoving Countries. London: John Hopkins University Press.

Grindle, M.S. 1980. Politics and Policy Implementation in The Third Word. New Jersey: Princeton University Press.

Islamy, M. Irfan. 2004. Prinsip-Prinsip Perumusan Kebijakan Negara. Jakarta: Bumi Aksara.

Jones, Charles O. 1984. An IntroductionbTo The Studi Of Public Policy. Third Edition. California: Wadsworth,Inc.

Lane, Jan Erick. 1993. The Public Sector. London: Sage Publications.

Mazmanian, D.A. \& Paul A. Sabatier. 1983. Implementation and Public Policy. London: Scott, Foresman and Company.

Pressman, J.L. \& Aaron Wildavsky. 1978. Implementation: How Great Expectation in Washington are Dased in Ockland. London: California Press.

Ripley Randall B, Frenklin. 1986. Policy Implementaion and Bureaucrazy, Chicago : The Dorsey Press.

Tachjan. 2008. (cetakan kedua), Implementasi Kebijakan Publik. Bandung: AIPI Bandung - Puslit KP2W LEMLIT UNPAD.

Van Meter, Donald S., and Van Horn, Carl E, 1975, The Policy Implementation Process: A Conceptual Framework. Administration and Society.

Moh. Nazir. 1988. Metode Penelitian. Jakarta: Ghalia Indonesia.

Panuju, Redi. 1995. Komunikasi Bisnis. Jakarta: PT Gramedia Pustaka Utama.

Sutopo dan Adi Suryanto. 2003. Pelayanan Prima. Jakarta: LAN RI. 
Umar, Husein. 2000. Riset Sumber Daya Manusia Dalam Organisasi. Jakarta: Gramedia Pustaka Utama.

Wahab, Solichin. 2004. Analisis Kebijaksanaan. Jakarta : Bumi Aksara

Winarno, Budi. 2002. Teori dan Proses Kebijakan Publik Yogyakarta: Media Pressindo

\section{Sumber Lain:}

AZ, Frans. 2011. Persaingan Indomaret-Alfamart dan Menjeritnya Pedagang Tradisional. http://ekonomi.kompasiana.com/bisnis/2011/05/05/persainganindomaret-alfamart-dan-menjeritnya-pedagang-tradisional/

Irenbodo. 2011. Model Kebijakan Publik.

http://www.irenbodo.blogspot.com/2011/01/model-kebijakanpublik.html?zx=514ebf46df89116e

Kompas. Edisi 11 Mei Tahun 2007.

Persatuan Warung dan Pasar Tradisional (Pesat). 2009. http://gresnews.com/ch/Regional/cl//id/1809531/read/1

Ratuagung. 2010. Implementasi Kebijakan. http://ratuagung78.blogspot.com/2010/02/implementasi-kebijakan-bottomup-dan.html

Setianingsih, Yatni. 2011. Pemkot Akan Data Ulang Minimarket di Bandung. http://www.inilahjabar.com/read/detail/1363262/pemkot-akan-data-ulangminimarket-di-bandung 